\title{
A Taste of Georgia. Far Right Populism with a Unique Georgian Flavour
}

\begin{abstract}
Georgia has proved no exception to recent political trends which have seen the increased prominence and influence of far right populist parties and movements purporting to represent 'the people' in an antagonistic struggle against the 'elites' or 'enemies'. However, while a great deal of academic attention has been devoted to cases in Central and Western Europe (CWE), studies of Georgian far right populism are much less common.
\end{abstract}

Therefore, this paper first examines the political styles of two Georgian far right actors, the Alliance of Patriots of Georgia (APG) and Georgian March (GM). I argue that the populist discursive frames both employ demonstrates enough commonalities with their CWE counterparts to consider them members of the far-right populist 'family'. However, the prevalence of populist ways of 'doing politics', highly influential role of 'traditional values' promoted by the Georgian Orthodox Church (GOC), and influence of Russia, are three important factors which produce a uniquely Georgian 'flavour' to far right populist movements in Georgia.

Keywords: Populism, Georgia, Far Right,

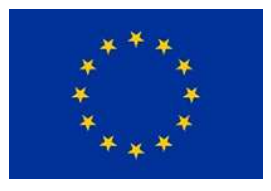

This research is part of a project that has received funding from the European Union's Horizon 2020 research and innovation programme under grant agreement No. 765224.

9473 Words (Including Tables) 
Michael Cole

University of Tartu

Early Stage Researcher - Fatigue

\section{A Taste of Georgia? Far Right Populism with a Unique Georgian Flavour}

\subsection{Introduction}

Georgia has proved no exception to recent political trends which have seen the increased prominence and influence of far right populist parties and movements (Samkharadze, 2020:1) purporting to represent 'the people' in an antagonistic struggle against the 'elites' or 'enemies' (Caiani and Della Porta, 2011; DeHanas and Shterin 2018:179; Laclau, 2005). However, while a great deal of academic attention has been devoted to cases in Central and Western Europe (CWE), studies of Georgian far right populism are much less common (Jgharkava, 2017:4).

Therefore, this paper first examines the political styles of two far right populist actors, Alliance of Patriots of Georgia (APG) and Georgian March (GM), arguing that both share enough characteristics to be classified as members of the European far-right populist 'family'. However, the prevalence of populist ways of 'doing politics', highly influential role of 'traditional values' promoted by the Georgian Orthodox Church (GOC), and influence of Russia, are three important factors which produce a uniquely Georgian 'flavour' to far right populist movements in Georgia.

A subsequent analysis of reactions by APG and GM to two high-profile incidents in Georgia demonstrates the importance of these three factors in influencing the content of Georgian far-right populist discourses.

\subsection{Populism}

Despite widespread agreement that the rise of populism is one of the most important political trends of modern times, a universally accepted definition of the term has proved notoriously elusive to reach (Brubaker, 2017:44). According to Mudde's (2004) widely cited conceptualisation, populism should be understood as a 'thin-centred' ideology which views 
Michael Cole

University of Tartu

Early Stage Researcher - Fatigue

society as dichotomously divided in an antagonistic struggle (Caiani and Della Porta, 2011) between 'the people' (DeHanas and Shterin 2018:179) and the 'elites'. For Mudde (2004), populist ideology's 'thin-centredness' is a result of being less developed than 'full' ideologies such as socialism or conservatism (Stanley, 2008:99), necessitating the incorporation of additional ideological components to become 'full' (Mudde and Kaltwasser, 2017:6). This need to absorb other ideological features (Stanley, 2008:95) means the precise worldviews promoted by populist parties and movements vary according to the national context in which they operate.

However, the concept of a 'thin-centred' ideology, which Mudde (2004) uses as a basis to explain the, at times, considerable differences between populists in different national contexts appears to contribute to the ambiguity, rather than assist in clarifying the concept of populism (Aslanidis, 2016a). For Freeden (1998), who coined the term, 'thin-centred' ideologies are those including nationalism, feminism and green thinking, which by nature only attempt to address a narrow range of political issues. In contrast, 'full' ideologies such as conservatism and liberalism provide much broader systems of understanding through which to interpret a far wider range of events, actions and social issues (Freeden, 1998). Yet despite the relative ease in drawing theoretical distinctions between 'full' and 'thin' ideologies, in practice, precise criteria to determine what constitutes a broad enough range of issues to be considered a 'full' rather than 'thin' ideology remain unclear (Aslanidis, 2016a), meaning classifications may derive as much from interpretations or emphasis as from scientifically discernable features (Humphrey, 2013).

Therefore, to avoid the potential ambiguity caused by reliance on the notion of a 'thincentred' ideology, this study instead understands the widely varied manifestations of populism in different national contexts as baring a 'family resemblance' to one another (Brubaker, 2017:8). Thus, although ideological or discursive similarities may exist between populists in different countries, there are no requisite features, which can be described as inherent to all populist movements (Brubaker, 2017:9). Instead, populism is deemed to be present when a sufficient amount of populist characteristics are observed in the discourse and actions of political actors (Brubaker 2017:9). This also means that populism is considered to be a gradable feature of wider 
Michael Cole

University of Tartu

Early Stage Researcher - Fatigue

discursive repertories, and is employed by political actors, to a greater or lesser degree depending on the situation (Arcimavičienè, 2018:92).

Despite the substantial variation between ideological views they promote, it is usually through discursive practices (Moffitt, 2016) that populists draw on a range of culturally specific features (Stanley, 2008) to construct imaginations of 'the people' (Laclau, 2005) whom they claim to represent (Caiani and Della Porta, 2011). In populist discourses, 'the people' are characteristically portrayed as homogeneously (Stanley, 2008) 'pure' (Mudde, 2004:543) and emanating from an idealised national 'heartland' (Breeze, 2018:28). This discursive construction tends to fuel both a nostalgic longing for the nations' past glories, whilst also invoking a heightened awareness of the need to defend it from external threats (DeHanas and Shterin, 2018:179). However, even within the same country, the content of populist discourses can differ greatly between political actors, and also changes over time (Brubaker, 2017:8). To account for these variations, this study understands populism as a political style, or 'way of doing politics' that utilises a populist 'discursive frame' (Aslanidis, 2016a).

A 'discursive frame' is a strategic tool political actors employ when presenting information to convince audiences of a specific interpretation of objects and events which is consistent with their broader political agendas or worldviews (Goffman, 1974:21). Thus, the populist discursive frame is used to present events and actions as resulting from the antagonistic struggle between 'the people' and 'the elites' or 'enemies', thus reinforcing this aspect of the populist political style. This understanding of populism accounts for both the ambiguity and opportunism considered typical of populist political actors (Odmalm and Hepburn, 2018:3), whose ideological stances are readily adapted according to the national and temporal context in which they operate (Aslanidis, 2016a:95). This non-normative and non-ideological conceptualisation of populism is also compatible with understandings that the complex set of features connecting populist actors in different contexts is analogous to a 'family resemblance', rather than the essential presence or absence of certain universal characteristics (Brubaker, 2017). Discourse-based studies are thus best suited for studies of populism (Brubaker, 2017) as they prioritise reaching deeper understandings of the unique local supply-side and demand-side 
Michael Cole

University of Tartu

Early Stage Researcher - Fatigue

factors contributing to support for political actors employing populist discursive frames in concrete situations, over attempts to identify universal ideological foundations upon which all manifestations of the phenomenon are based (Mudde and Kaltwasser, 2012:9).

Although these supply-side and demand-side factors vary widely according to local and national contexts, having a charismatic leader is usually considered a reliable indicator of populist success (Aslanidis, 2016a:96). The term 'charismatic' is rather challenging to define in absolute terms (Pappas, 2016:1), and to a large extent is situationally dependent. However, charismatic leaders generally have a strong ability to project their ideas in ways that convince wider audiences to support them. While this certainly means that not all charismatic leaders should be labelled populist, a persuasive orator employing the populist discursive frame might be considered to possess enough 'political charisma' to significantly improve his or her party's potential for electoral success and societal influence.

An important component of the populist style is the use of this discursive frame to portray party or movement leaders as 'one of the people', thus justifying their credentials to represent them. The boundaries between political and personal spheres thus have a tendency to become blurred, as the frame is used to convince audiences to accept a political leader's portrayal of reality (Benford and Snow, 2000). A second important characteristic of the populist style is the aim to convince audiences of a leader's credentials as defenders of 'the people', and often by extension 'the nation' via the re-articulation of familiar cultural features and symbols (Swidler, 1986; Aslanidis, 2016a). This strategic employment of cultural symbols as “...meaning making devices..." (Aslanidis, 2016b, 304) is a significant way to foster positive audience associations of political leaders as defenders of national identity. 'Political charisma' is thus understood, according to Pappas' (2016:9) definition ,as encapsulating not only a highly personal leadership style, but also one which seeks to radically transform or redefine the established political order. In this regard there appears to be more than a coincidental connection between the qualities of a charismatic leader and the worldview articulated through the populist discursive frame. 
Michael Cole

University of Tartu

Early Stage Researcher - Fatigue

Therefore this study conceptualizes populism as a political style or 'way of doing' politics whereby political actors employ a specific discursive frame which presents events and actions as resulting from a society which is dichotomously divided in an antagonistic struggle between the 'pure people' and the 'corrupt elites' or 'enemies' (Moffitt and Tormey, 2014:387; Laclau, 2005). The populist discursive frame is one tool of several available to political actors as part of a wider discursive repertoire. Because populism is understood not as an absolute quality of individual political actors, but as a gradable phenomenon (Arcimavičienè, 2018:92), both the degree to which the populist frame is employed, and the exact discursive content which it contains are greatly dependent on local context (Aslanidis, 2016a: 99-100). Potential for populist success in most situations is positively impacted by the presence of a charismatic leader (Aslanidis, 2016a:96), able to employ the populist discursive frame in ways which harness familiar cultural symbols (Aslanidis, 2016b, 304) to connect positively with the public. As populism is most commonly displayed through discourse (Moffitt, 2016), it is first necessary to clarify this equally elusive concept.

\subsection{Discourse}

The term 'discourse' is used with increasing regularity in a wide range of academic and non-academic fields. However, its precise meaning is perhaps even more debated than that of populism (Sawyer, 2002:434). Many studies appear to simply accept discourse as a rather vague concept emanating from Foucault, which involves, but is certainly not limited to language and its influence on broader social patterns of behaviour and power (Sawyer, 2002:434). The initial benefits that this conceptual vagueness may have initially provided to academic studies in various fields, has since caused a lack of clarity when applying the concept to concrete empirical cases (Müller, 2008:323). To provide greater precision regarding the understanding of discourse, this study employs a combination of both post-foundational and critical discourse theories, which will now be briefly discussed in turn. 
Michael Cole

University of Tartu

Early Stage Researcher - Fatigue

\subsection{Post-Foundational Discourse Theory}

From a post-foundationalist perspective, the aim of discourse analysis is to uncover existing hegemonic power systems, the maintenance and dissemination of which engages societies in a continuous struggle for dominance (Makarychev and Sazanov, 2019:1). Discourse is not seen as in any way separate from reality (Carpentier, 2019:157), hence Laclau and Mouffe's (2001:107-110) rejection of the connection between language use and social actions. Discourse is instead understood as a fluid and evolving set of interconnected phenomena encompassing all features of the social world, which create meaning through their various combinations with each other (Carpentier, 2019:157).

For Laclau and Mouffe (2001:113) these meanings never remain fixed for long periods of time, as they are continually negotiated and reimagined through discursive interactions in different situations (Laclau, 1988:254). However, discourses must be temporarily stable to allow networks of meaning to develop around them (Carpentier, 2019:157). The ability to decide both the points and arrangements in which discourses become fixed, is a political act, usually reserved by the hegemonic power (Carpentier, 2019:158), which can establish a fixed discourse through the exploitation of culturally resonant 'nodal points'.

Particular 'nodal points' known as 'empty-signifiers' (Laclau, 1996:53), provide a central hub around which related concepts can be arranged, creating larger webs of association, and retroactively contributing to the perceived meaning of the initial term (Cederström and Spicer, 2014:190). Because empty-signifiers lack fixed meanings and remain vaguely defined, a range of different, and frequently contradictory characteristics can be attributed to them (Giesen and Seyfert, 2016:115). However, the tendency for certain empty-signifiers, such as 'the people' in populist discourses, to recur as resonant nodal points, suggests that it may be more accurate to suggests that they are 'almost empty', and therefore not entirely void of inherent meaning (Brown, 2016:119-120).

Discourses are selections of related ideas and objects, which are collected under the umbrella of empty-signifiers (Howarth and Stavrakakis, 2000:11) according to either the logic of equivalence, or logic of difference. The logic of equivalence conceptualises reality as a polarised 
Michael Cole

University of Tartu

Early Stage Researcher - Fatigue

arrangement where all objects and ideas belong to one of two opposing sides, which are represented by mutually exclusive empty-signifiers (Howarth and Stavrakakis, 2000:11). This allows a 'chain of equivalence' Laclau (2005) to be formed, whereby networks of contradictory and contrasting ideas appear to unify around a common empty signifier, which is thus taken as simultaneously representative of all these different meanings and associations. Contrastingly, the logic of difference portrays the world as too complex for these dichotomous divisions between two opposite poles (Howarth and Stavrakakis, 2000:11). Thus, rather than combining a range of potentially varied objects and ideas under an overarching empty signifier that represents them all, the chain of equivalence is divided into its component parts, with each understood and therefore treated individually (Chryssogelos, 2018:6).

\subsection{Critical Discourse Theory}

Although this study accepts post-foundationalist views that discourse is not limited exclusively to language, as the material manifestation of ideas and practices, written and spoken texts provide the most practical medium through which discourses can be identified and systematically analysed (Hodge and Kress, 1988:5-6). It is therefore necessary to complement post-foundationalism with critical discourse theory, which defines discourse as social practice (Wodak and Fairclough, 1997:258), and, crucially, places language in a central role (Locke, 2004:11) to both influence and be influenced by, power relations in society.

Critical discourse studies aim to identify the relationships between ideology and power, as well as ways language contributes to the maintenance, promulgation and revelation of these relationships (Breeze, 2011:495). Because this interplay is a key aim of critical discourse research (Wodak and Fairclough, 1997), analyses focus on language's social and political functions, rather than the purely structural features (Breeze, 2011:495), in order to reveal patterns of inequality which are reproduced through language use (Forchtner, 2011:1). For instance, the exploration of intertextuality and interdiscursivity in critical discourse studies examines how power relationships are constructed and negotiated, as well as maintained or challenged through 
Michael Cole

University of Tartu

Early Stage Researcher - Fatigue

linguistic processes (Fairclough, 1992). In this sense, critical discourse studies complement postfoundationalist understandings of discourses as collections of ideas and under empty signifiers, by providing the tools to identify the presence of and determine wider patterns of meaning (Laclau, 1996:53).

Critical discourse studies have been criticized for simply borrowing ideas and theories about society from a range of often contradictory sources, making it challenging to identify a systematic intellectual basis connecting such varied approaches to research (Breeze, 2011:501). However, the lack of a theoretical or philosophical 'strait-jacket' ought to be seen as advantageous in allowing the scope to draw on an eclectic range of perspectives to select those best-suited to individual research projects (Weiss and Wodak 2002). Therefore, the benefit of basing critical discourse approaches upon post-foundationalist theoretical foundations, is the range of analytical tools that the former provides to detect instances when these discourses become temporarily fixed to certain nodal points around which discourses collect. Allowing for the possibility that discursive features are not limited to just language, (Wodak and Fairclough, 1997), and that discourses consist of both language and practice (Müller, 2008:324) appears to satisfy both apparently incompatible approaches. Before utilizing this combination of theoretical and practical tools to examine far-right populist discourses in Georgia, it is first necessary to position the case studies selected in relation to similar groups elsewhere via an overview of the literature related the far, radical and extreme right.

\subsection{The Far, Radical and Extreme Right}

Mudde (2014:98), divides the far right into two largely distinct categories, according to attitudes regarding democracy and democratic practices. In his view, the extreme right consists of those actors entirely opposed to democracy, who seek to gain power through non-democratic means (Mudde, 2014:98). In contrast, radical right groups are prepared to use democratic processes to gain power and believe in the necessity of competing in elections to do so (Mudde, 2014:98). However, rather than resulting from genuine ideological support for parliamentary democracy the use of democratic practices by radical right groups is perhaps best understood as 
Michael Cole

University of Tartu

Early Stage Researcher - Fatigue

predominantly strategic (Kallis, 2018:81). With the knowledge that democratic systems can be successfully exploited to gain influence and power, radical right parties can also boost their perceived legitimacy by being seen to adhere to conventional parliamentary processes (Kallis, 2018:86; Williams, 2018:443). In this regard, the most striking feature distinguishing radical from extreme right is that the former does not entirely oppose participating in a democracy (Mudde, 2014:98). Radical right parties thus only oppose certain features of liberal democracy including minority rights and pluralism, and not necessarily the democratic system in its entirety (Mudde, 2014:98). However, though these distinctions between radical and extreme right may be well-suited to examples in Central and Western Europe, for application in the Georgian context, some adaptations are necessary.

\subsection{The Georgian Far Right}

International media coverage of the Georgian far right has increased considerably since 2017 when the March of Georgians combined various right wing and nationalist groups to form a street protest in Tbilisi against increased immigration (Jgharkava, 2017:4). Although the organisers remain quite marginalised (Stephan, 2018:1), and some smaller groups opted not to participate (Pertaia, 2017), the march was joined by Georgian MPs and well-known members of the political establishment (Jgharkava, 2017:4). The unified nature of the March of Georgians thus appears to demonstrate ideological similarities and connections between far right Georgian actors ranging from football hooligans and organised street movements to fully-fledged political parties with seats in parliament (Baranec, 2018). The additional tendency in Georgia for street movements of all stripes to evolve into political parties (Jones, 2015) also highlights the challenge of uncritically adopting Mudde's (2014:98) conceptualisations of 'far', 'radical' and 'extreme' right for application in the Georgian context.

Therefore, this study conceptualises far right actors in Georgia as those who not only promote highly nativist ideological agendas, but also combine this with a propensity to either 
Michael Cole

University of Tartu

Early Stage Researcher - Fatigue

partake in, or encourage violent actions to support their aims. This conceptualisation excludes parties who may promote borderline nativist ideologies but do not combine them with calls for, or involvement in, violent acts against perceived enemies. The Georgian radical and extreme right are distinguished on account of the former only calling for aggressive acts to support their aims, whilst the latter actively participate in violence. According to these classifications, the two subjects of this study, Alliance of Patriots of Georgia (APG) and Georgian March (GM), are both considered members of the far right. APG are classified as radical right, because although individual members have joined aggressive protests against migration and LGBT rights, officially the party has resisted taking a leading role (Gotsiridze, 2018). However, APG's reluctance to be openly involved belies their regular calls for violent and discriminatory acts against minorities in Georgia (Gotsiridze, 2018). GM are classified as extreme right, because despite apparent ambitions to form a political party (Stephan, 2018:6), they are primarily involved in aggressive and violent street protests against minority groups (Wales, 2017).

Both APG and GM have also been labelled populist (Silagadze, 2020:5; Stephan, 2018:3) for promoting discourses which claim to defend the interests of a homogeneous and exclusive understanding of 'the people' (Stephan, 2018:3; Abashidze, 2018), in opposition to a set of enemies or elites. In doing so, both groups incorporate specific cultural elements with strong connections to societal understandings of Georgian identity, which serve as nodal points around which their wider discourses are formed, and enhance their image as representatives of 'the people'. What follows is a more systematic analysis of APG and GM's ways of 'doing politics' showing the extent to which they conform to the criteria for identifying populism outlined in Section 2.0.

\subsection{Alliance of Patriots of Georgia}

Alliance of Patriots of Georgia (APG) gained six seats in the 2016 parliamentary elections with their 'Georgia First' campaign, which underlined the synonymity of Orthodox Christian beliefs and Georgian national identity (Stephan, 2018:3). While APG's increased support can largely be attributed to their emphasis on protecting Orthodox Christian values from 
Michael Cole

University of Tartu

Early Stage Researcher - Fatigue

the perceived threat of ethnic and sexual minorities it has also, perhaps paradoxically, created space to foster closer relations with Russia (Wales, 2017). APG leaders have held several recent meetings with Russian government officials in Moscow, despite the two countries having suspended diplomatic ties following the 2008 war (Morrison, 2018b). Officially APG deny accusations of being pro-Russian 'lobbyists' (Morrison, 2018b), describing their reconciliatory approach as pragmatic in light of the potential economic benefits Georgia stands to gain should relations with Moscow improve (Baranec, 2018:6).

\section{'The People'}

According to their manifesto, APG supporters are those who value "...the homeland, faith in God, love for everything Georgian, and respect for the native language" (Alliance of Patriots of Georgia: Our Vision and Program, 2020). These four characteristics used to define the qualities of 'the people' are familiar to Georgian audiences as the words of nineteenth century poet and national patriot Ilia Chavchavadze, who characterized the nation's values as 'Fatherland, Language, Faith' (Kekelia, 2014:123). However, by placing 'faith in God' before both 'love for everything Georgian' and 'language', APG's version of Chavchavadze's wellknown slogan shows close alignment with an alternative interpretation preferred by the Georgian Orthodox Church (GOC), whose Patriarch Ilia II states that Orthodoxy should be the primary defining characteristic of Georgian national identity (Minesashvili, 2017:7).

This construction of 'the Georgian people' based on Orthodox religious homogeneity is evident throughout APG's online discourse which describes Georgian patriotism as requiring 'conformity with the national spirit' (Alliance of Patriots of Georgia: Our Vision and Program, 2020). A section entitled 'Let's Appreciate our Patriarch' in the 'Our Program, Our Vision' section of APG's website draws on predominantly religious language and symbols to explain Georgia's societal and political problems as well as how best to overcome them. The page contains eighteen separate instances of the word 'God' as well as other religious keywords such as 'faith' and 'Satan', in a passage conflating Georgia's national development with the battle between God and Satan. 
Michael Cole

University of Tartu

Early Stage Researcher - Fatigue

Although the promotion of Georgian Orthodoxy is evident throughout APG's website, there are also positive references to other religious faiths including Islam and Judaism. However, the emphasis lies on those common values other religions share with Christianity, notably the need 'not to kill people, no matter how strongly someone has offended us' (Alliance of Patriots of Georgia: Our Vision and Program, 2020). In this way, Georgian Orthodox identity is positively evaluated as 'extremely tolerant' and 'free from ethnic and religious hatred' as well as 'open to other nations' (Alliance of Patriots of Georgia: Our Vision and Program, 2020). However, this tolerance is qualified with the caveat that 'our freedom ends, where another's abuse begins' (Alliance of Patriots of Georgia: Our Vision and Program, 2020), which appears to justify the assertion of Orthodox Christian values should outside influences be perceived to threaten Georgian values.

In the section of their official website entitled 'Who are the Supporters of the Alliance of Patriots of Georgia?' (Alliance of Patriots of Georgia: Our Supporters, 2020) APG's understanding of 'the people' appears to be clearly articulated via thirteen constructed examples of archetypal APG supporters under the heading 'A Supporter of the Alliance of Patriots of Georgia is...' (Alliance of Patriots of Georgia: Our Supporters, 2020) (See Table 1 below). The range of example supporters is chosen to demonstrate the apparent diversity of APG's appeal, from taxi drivers to doctors, and is summarized by the concluding statement "We are present in every stratum and category of society!” (Alliance of Patriots of Georgia: Our Supporters, 2020) In combination, the typical characteristics of each 'APG Supporter' appear to reflect key features of a populist discursive frame. Each definition contains a positive evaluation of the 'APG Supporter' who wishes for an improved Georgia, visible in Table 1 (below), with five of the descriptions also containing evidence of an antagonism against a negatively depicted elite actor (Table 2).

The populist trait of invoking notions of an idealized national 'heartland' to which the people belong (Breeze, 2018:28) is evident in the direct use of the word 'homeland' in five of the descriptions ('Taxi Driver', 'Journalist', 'Georgian Immigrant' and 'Every Mother'). APG's understanding of those who are included in definitions of 'the people' is further evidenced in the descriptions of 'A Georgian Immigrant' and 'A Refugee from Sukhumi and Tskhinvali'. The former 'character' shows that APG include ethnic Georgians living outside Georgia in 
Michael Cole

University of Tartu

Early Stage Researcher - Fatigue

constructions of 'the people', because they work to 'help their own family and country' (Alliance of Patriots of Georgia: Our Supporters, 2020) and the latter ensures that those from territories occupied by Russia since 2008 who are living in Georgia are also included. Though APG assert that their supporters “....will never become any other country's slaves” (Alliance of Patriots of Georgia: Our Supporters, 2020), the failure to explicit mention Russia as responsible for the situation may support claims that APG have pro-Russian tendencies (Morrison, 2018a). It also notable that only refugees from Sukhumi and Tskhinvali who are now living in Georgia are included in this construction of 'the people', whereas those still living in the affected regions are omitted. Though this does not necessarily indicate that APG are promoting a Russian narratives surrounding the geopolitical situation in the region, it does appear to suggest an attempt to avoid directly attributing blame to Russia for instigating and prolonging the conflicts.

\begin{tabular}{|c|c|}
\hline $\begin{array}{l}\text { Archetypal APG } \\
\text { Supporter }\end{array}$ & Positive Characteristic \\
\hline A scientist & sees that science is promptly dying out in Georgia \\
\hline An architect & $\begin{array}{l}\text { in the eyes of whom Tbilisi has entirely lost its historical } \\
\text { appearance, spirit and character, while the heart of this architect is } \\
\text { aching for his native city... He perfectly knows how to help his city, }\end{array}$ \\
\hline An educator & whose profession is extremely undervalued in Georgia \\
\hline A doctor & $\begin{array}{l}\text { who knows better than anyone, how hard all those who come to him } \\
\text { live, while the doctors themselves suffer need not less than their } \\
\text { patients }\end{array}$ \\
\hline $\begin{array}{l}\text { A refugee from } \\
\text { Sukhumi and } \\
\text { Tskhinvali }\end{array}$ & $\begin{array}{l}\text { who is confident that we will never cede our Georgian lands, and } \\
\text { that we will never say that Abkhazia is not the part of Georgia. He } \\
\text { is sure that we will never become any other country's slaves. }\end{array}$ \\
\hline A taxi driver & $\begin{array}{l}\text { who drives his old, decrepit car through the day and night to feed } \\
\text { his family... However, he will never say, "I'm tired", but he will }\end{array}$ \\
\hline
\end{tabular}




\begin{tabular}{|c|c|}
\hline & $\begin{array}{l}\text { always be the first to come to a protest action, because he is a true } \\
\text { patriot, and his heart is full of love for his Homeland. }\end{array}$ \\
\hline $\begin{array}{l}\text { A family with } \\
\text { dependent children }\end{array}$ & $\begin{array}{l}\text { which is hungry and thirsty. This family strongly believes that we } \\
\text { won't be able to sleep at night if we warm our own children, while } \\
\text { leaving other people's children to be cold. This is why these } \\
\text { families are with us... }\end{array}$ \\
\hline A citizen & $\begin{array}{l}\text { who wants to live in a fair state, which is not just a territory for } \\
\text { him... His Homeland, his native language and his faith are vitally } \\
\text { important for him }\end{array}$ \\
\hline A journalist & $\begin{array}{l}\text { for whom journalism doesn't mean working in the propaganda } \\
\text { services and collecting compromising materials. }\end{array}$ \\
\hline $\begin{array}{l}\text { A Georgian } \\
\text { immigrant }\end{array}$ & $\begin{array}{l}\text { who carries out backbreaking labor abroad to help his own family } \\
\text { and country... This immigrant perfectly knows the value of labor } \\
\text { and Homeland }\end{array}$ \\
\hline A citizen & $\begin{array}{l}\text { who wants his children to live in the state, where no one will steal } \\
\text { their votes, and where the human and constitutional rights of the } \\
\text { citizens will never be violated. }\end{array}$ \\
\hline Every mother & $\begin{array}{l}\text { who wants her children to be grown up freely in their own } \\
\text { Homeland, and with their native traditions }\end{array}$ \\
\hline
\end{tabular}

Table 1: 'A Supporter of the Alliance of Patriots of Georgia is...' (patriots.ge/oursupporters)

\section{'The Elites / Enemies'}

The populist political style not only involves an appeal to the 'pure people', but also includes a portrayal of the 'elites' or 'enemies' who oppose them (Moffitt and Tormey, 2014:387; Laclau, 2005). The 'Who are the Supporters of the Alliance of Patriots of Georgia?' section of APG's website equally demonstrates how APG incorporate this feature of the populist discursive frame. The examples of 'APG Supporters' also contain descriptions of personal 
Michael Cole

University of Tartu

Early Stage Researcher - Fatigue

struggles to overcome the existing corrupt Georgian political system in order to contribute positively to the goals of the nation (Alliance of Patriots of Georgia: Our Supporters, 2020). This inherent 'purity' of 'APG Supporters' is perhaps most clearly articulated in the five examples shown in Table 2 (Below), where they are most clearly contrasted with the negative qualities of the elite. In each case, the 'APG Supporter' is portrayed as either better suited to solve Georgia's problems than those currently responsible for doing so (Scientist, Taxi Driver, Journalist), morally superior to the current authorities (Scientist, Journalist), or prevented from achieving positive outcomes for the nation by ineffective or corrupt elites (Scientist, Architect, Educator).

\begin{tabular}{|c|c|}
\hline $\begin{array}{l}\text { Archetypal APG } \\
\text { Supporter }\end{array}$ & Antagonism with 'the elite' \\
\hline A scientist & $\begin{array}{l}\text { The state has no will to declare the support and stimulation of the Georgian } \\
\text { science as a priority. The state not only has no will, but also doesn't even } \\
\text { know how to do }\end{array}$ \\
\hline An architect & $\begin{array}{l}\text { After all, he has neither an influential relative nor a friend who could give } \\
\text { him work and involve him in such a good deed as the preservation of the } \\
\text { historical face and colors of Georgia }\end{array}$ \\
\hline An educator & $\begin{array}{l}\text { while the education system is undeveloped and ineffective, distant, and } \\
\text { detached from any national values }\end{array}$ \\
\hline A taxi driver & $\begin{array}{l}\text { He perfectly distinguishes white, black, and gray, and he is a more } \\
\text { competent expert than most of the experts }\end{array}$ \\
\hline A journalist & For him, journalism means being unbiased and speaking the truth. \\
\hline
\end{tabular}

In addition to this general anti-elite discourse, APG also explicitly identify former Georgian Prime Minister Mikheil Saakashvili as an enemy to the Georgian nation. Saakashvili, who himself displayed clear populist tendencies when leading the 2003 Rose Revolution (Jones, 2015), continues to be influential, yet divisive in Georgian politics despite having remained outside the country since 2013 to avoid facing corruption charges (Karatnycky, 2018). APG 
Michael Cole

University of Tartu

Early Stage Researcher - Fatigue

describe Saakashvili's regime as 'tyrannical' four times on their website, and twice refer to 'crimes' his government committed against the Georgian people. The importance of 'Saakashvili' as an enemy figure in APG's discourse can also be gleaned from Party Chairman Davit Tarkhan-Mouravi's profile on the site, which foregrounds his 'decisive role in the downfall of Saakashvili's tyrannical regime' (Alliance of Patriots of Georgia: Our Party, 2020), ), ahead of the ostensibly superior achievement of receiving a Nobel Peace Prize nomination in 2013.

Demonstrating that this discourse goes beyond rhetoric, APG also organised a series of protests against Saakashvili, and the current government's 'cohabitation' with him, to coincide with upcoming elections (Morrison, 2018b). What these protests also highlight is APG's adoption of the collective term 'saakashvilis' to refer more broadly to enemies seeking to control Georgia (Civil.ge, 2018). At a 2018 demonstration, Party General Secretary Irma Inashvili is quoted as saying "Saakashvilis will not improve, and we won't let Georgia go to these maniacs" (Civil.ge, 2018). The term was used again by Davit Tarkhan-Mouravi in a 2019 Tbilisi rally where the Party Chairman called for 'saakashvilis' to be punished for failing to protect Georgian claims to the disputed Gareji monastery complex near the Azerbaijani border (Civil.ge, 2019). In this sense, rather than referring to Mikheil Saakashvili himself, the notion of a 'saakashvili' acts as an empty signifier, which here is easily recognisable to certain sections of the Georgian public as representing corrupt practices, and potentially also a lack of patriotism.

\section{'Charismatic Leader'}

Though not an essential feature of populist politics, charismatic leaders are considered highly influential in improving electoral appeal (Pappas, 2016:9). APG has two official leaders, Party Chairman Davit Tarkhan-Mouravi and General Secretary Irma Inashvili (Stephan, 2018:3). Tarkhan-Mouravi does not necessarily fit the populist prototype of appearing to be 'one of the people', due to his claims to be a direct descendant of Georgian royalty (Kucera, 2016). However, this image instead potentially enhances Tarkhan-Mouravi's image as a true representative of the Georgian people, while he has also attempted to garner favour by focusing 
Michael Cole

University of Tartu

Early Stage Researcher - Fatigue

on issues which may affect 'ordinary' Georgians. Most notably, Tarkhan-Mouravi claimed that Turkey was importing high quality Georgian potatoes and tomatoes from Georgia, and selling inferior products in return (Dangadze, 2019). Though the claims were ultimately false (Dangadze, 2019), the discursive approach both emphasises the quality of Georgian products, and by extension the Georgian people who produce them, while also incorporating anti-Turkish sentiment to foster the sense of a threat to the Georgian values of honesty and fairness.

Irma Inashvili was elected as one of six vice speakers of the Georgian Parliament in 2016 (Civil.ge, 2016) and has therefore attained a higher profile amongst the general public since. As Party Secretary, Inashvili has spearheaded several high-profile protests in Georgia to raise attention to APG's political goals, including staging a sixteen day hunger strike in 2015 to protest against electoral fraud (Democracy and Freedom Watch, 2015). Even more notably, Inashvili forcibly gained entry to a Tbilisi International Relations Conference at which APG were the only Georgian Party represented in parliament who had not been invited (Sikharulidze, 2019). Inashvili explained that she had appeared to 'brief the attendees about the party and our goals', though the disruption caused by her arrival led to a confrontation with former US Assistant Secretary of state David Kramer which was widely disseminated on social media (Agenda.ge, 2019). However, the incident seems indicative of the populist tendency to champion direct forms of democracy (Bar-On, 2018:60), and even gained approval in some quarters for drawing attention to both the closed nature of Georgian elite-level politics, and the tendency for such events to contribute little towards tackling the most important issues in Georgian society (Sikharulidze, 2019).

\subsection{Georgian March}

Unlike APG, Georgian March (GM) is not usually categorized as a fully-fledged political party, but instead a 'societal-level actor' (Silagadze, 2020:5). GM evolved from a coalition of far-right individuals and organisations, including some neo-Nazi groups and first became prominent in 2017 after organizing anti-immigration street protests in Tbilisi (Wales, 2017). GM 
Michael Cole

University of Tartu

Early Stage Researcher - Fatigue

are known for making homophobic statements under the guise of protecting 'traditional family values' (Stephan, 2018), and slogans they employ mirror those of other far right populist movements across Europe (Jgharkava, 2017:6).

\section{'The People'}

The homophobic and anti-immigrant rhetoric for which GM are best known is indicative of their conceptualisations of 'the people'. Leader Sandro Bregadze has described GM's political goals with the motto 'Georgian Georgia, not Georgia for Georgians' (Abashidze, 2018), which emphasizes desires for a pure, homogeneous society, intolerant of diversity. The slogan appears to have been carefully chosen to distance associations with those used by Georgia's first postindependence President Zviad Gamsakhurdia, who combined elements of "nationalism, populism, religiosity, and conservatism" (Jones, 2015: Chapter 3, Section 2, Para. 2). Although Gamsakhurdia's beliefs in the historical sacredness of the Georgian national idea (Gamsakhurdia, 1990) may not diverge too far from those promoted by modern-day far right groups, his isolationist policies alienated Georgia from both Russia and the West, resulting in the civil war of the early 1990s (Aphrasidze and Siroky, 2010:127).

The promulgation of 'Georgian Georgia' slogans encapsulates the belief in fixed definitions of a homogeneous Georgian identity, which excludes religious, sexual and ethnic minorities. These intolerant views toward sexual minorities are not a new phenomenon in the country (Minesashvili, 2017:6), with recent research suggesting that a large majority of Georgians consider LGBTQ people less desirable neighbours than members of any other minority group (Minesashvili, 2017:7). However, the regularity at which the issues have been raised in recent Georgian public discourse has contributed to the kind of increased polarization in society which is comparable to similar trends across Europe. 
Michael Cole

University of Tartu

Early Stage Researcher - Fatigue

\section{'The Elites / Enemies'}

Unlike APG's anti-elite discourse, which largely concentrates on figures within the Georgian system, most notably Mikheil Saakashvili, GM's construction of the elite appears to be more internationally focused. Closely resembling discourses produced by far right populist parties across Europe from whom they claim inspiration (Lomsadze, 2018), GM have organised protests against Jewish businessman and philanthropist Georgia Soros, who having invested considerably in Georgia, particularly in anti-corruption reform schemes (Horvath, 2011:17) has been identified by GM and other far right actors as a tangible symbol of perceived increasing Western imperialism, which they hold responsible for eroding traditional Georgian values (Morrison, 2018c). In a 2018 protest entitled 'Burn Soros - Save the Country', members of GM burned effigies of Soros, and demanded Georgia follow the examples of Hungary and Austria in forcing his Open Society Foundation to leave the country (Eurasia Daily, Burn Soros Save the Country, 2018). Thus, in what appears to be a strategic mirroring of likeminded movements elsewhere for the Georgian far right and GM in particular, as a well-known elite figure, Soros seems to have become a convenient empty-signifier representing a range of negative traits combining to destroy Georgian national identity by forcing Georgians to "become drug addicts or engage in prostitution, or altogether isolated from this world and to have this country taken over by absolutely different people" (Bregadze, Obieqtivi TV, 2018).

In addition to these anti-elite components, there are two main groups of enemies, which feature prominently in GM's discourse. Firstly, immigrants, especially those of Asian, African and Turkish origin, and secondly the LGBTQI community all of whom are considered threats to 'traditional Georgian values' (Abashidze, 2018). GM first gained international recognition for organising the March of Georgians in 2017 (Stephan, 2018:4), which united Georgian far-right groups in protest against immigration. The decision to hold the protests on Tbilisi's Aghmashenebeli Avenue was significant as the street contains a high number of restaurants owned by Arabic, Turkish and Iranian immigrants, whom GM connect to increased unemployment and social problems in Georgia (Pertaia, 2017; Jgharkava, 2017:6). The antiMuslim rhetoric is familiar from studies of similar movements in Western Europe, though, with Georgia bordering both Turkey and Iran, in this context it also includes issues related to the non- 
Michael Cole

University of Tartu

Early Stage Researcher - Fatigue

Georgian ownership of agricultural land (Kvakhadze, 2018), which may add some perceived social legitimacy and enable an element of deniable plausibility against accusations of overt racism

While immigrants provide a constructed external enemy against whom GM claim the Georgian 'people' need to be defended, the LGBTQI community are additionally presented as an internal threat to Georgian values. GM have capitalised on widespread anti-LGBTQI sentiment in Georgian society (Gelashvili, 2019:8), to reinforce beliefs that increased rights for sexual minorities are a foreign imposition detrimental to Georgian ways of life. Not only do these views tend to align with the ideological position of the Georgian Orthodox Church (GOC), but the GOC's active, and at times aggressive, role in attacking LGBT Pride events in the country (Thousands Protest in Georgia: BBC, 2013) has further validated them. Thus, appear to have increasingly emphasised the anti-LGBTQI aspects of their agenda, in what may be a means of increasing both media exposure and perceived credibility by aligning themselves with the most trusted institution in Georgia (Minesashvili, 2017:2).

\section{'Charismatic Leader'}

Georgian March Leader Sandro Bregadze is a former Deputy Minister of Foreign Affairs (Stephan, 2018:4) who claims inspiration from Marine Le Pen (Lomsadze, 2018) and Donald Trump (Georgia's Rave Revolution: BBC News, 2018). Similar to the leaders of Alliance of Patriots of Georgia, Bregadze has engaged in several populist moves to raise the profile of both himself and Georgian March, including the organization of hunger strikes (Lomsadze, 2018) and patrolling Tbilisi's streets to stop crimes being committed by 'suspicious foreigners' (Democracy and Freedom Watch, 2018). Bregadze also led a group of GM members in a violent confrontation with Giorgi Gabunia, a moderator of the Rustavi-2 Television Channel, following a joke which was deemed to offend Orthodox Christian sensibilities (Mchedlishvili, 2018). In each case, Bregadze cultivates a public image of a strongman, prepared to resort to violent action to defend traditional Georgian values from perceived threats. 
Michael Cole

University of Tartu

Early Stage Researcher - Fatigue

\section{3 'Georgian Flavour'}

The employment of populist discursive frames, which imagine the world as dichotomously between 'the people' and 'elites' or enemies, by a charismatic leader seeking to radically redefine the political order (Pappas, 2016:9) enables commonalities to be drawn between APG and GM far right populists in other contexts. However, viewing populism as a 'way of doing politics' (Aslanidis, 2016a) also allows for their uniquely Georgian discursive features, which not only differentiate them from their Central and Western European contemporaries, but also have a considerable bearing on their potential to appeal to Georgian audiences. An analysis of APG and GM's 'ways of doing politics' suggests three context-specific factors which combine to produce a specifically Georgian brands of far right populism.

Firstly, in Georgian politics, populism is not a rare, nor new phenomenon, and has been a much more common feature of the country's political environment than in other more developed Western European democracies (Silagadze, 2020). Populist ways of 'doing politics' (Aslanidis, 2016a) are thus common in mainstream Georgian politics and, as in other countries transitioning from autocratic forms of government, should not always be evaluated as detrimental to the democratisation process (Mudde and Kaltwasser, 2017:20). The confrontational style of personality driven politics practiced by GM's Sandro Bregadze and APG's Irma Inashvili has much in common with the approaches of former presidents Mikheil Saakashvili and Zviad Gamsakhurdia (Jones, 2015). The additional tendency for street movements and broad coalitions of political figures and groups to evolve into fully-fledged political parties (Jones, 2015) means neither APG nor GM can be considered remarkable in terms of the approaches they adopt.

Secondly, a key feature of Georgian far right populist discourses is the underlying belief that liberal Western values are incompatible with notions of Georgian national identity (Lebanidze, 2016:2), which is instead based on deep-rooted patriarchal norms (Mestvirishvilli et al., 2017:1256). These views are fostered by the highly influential Georgian Orthodox Church (GOC), which has come to present itself as synonymous with the modern brand of 'Georgianness' that emerged following independence from the Soviet Union and, has been 
Michael Cole

University of Tartu

Early Stage Researcher - Fatigue

significantly reinforced since the 2003 Rose Revolution (Zedania, 2011:123). Inglehart and Norris (2016:25) have previously identified correlation between strength of religiosity and support for populist parties, and this connection of religious homogeneity to national identity draws comparisons with successful Polish and Hungarian right-wing populists' utilization of Christianity to increase their legitimacy (Adam and Bozoki, 2016). However, the Georgian Orthodox Church (GOC)'s positon as the most trusted institution in the country (Minesashvili et al., 2017:2), means there is an even greater need than elsewhere for successful political parties of all stripes to align themselves with the values it promotes if they intend to be successful (Zedania, 2011:125). Thus the highly religious content of Georgian far right populist discourses is often not that distinct from the views promoted by mainstream political parties, and appears to reflect local demand-side factors (Gelashvili, 2019:8). In practice, this may better facilitate the construction of chains of equivalence centring on religious and national symbols, which can be easily co-opted by political actors promoting extreme views (Gelashvili, 2019:8).

Owing to Georgia's position outside the European Union, far right populist movements are better defined as Euro-sceptics rather than openly anti-EU, unlike many of their Central and Western European counterparts. Widespread acceptance of church-promoted illiberalism under the guise of 'traditional Georgian values' may appear to contradict the overwhelming support amongst the Georgian population for EU and NATO accession (EU Neighbours Annual Survey Report, 2017). However, this apparent paradox instead seems to highlight that ordinary Georgians more often value tangible gains that such associations can provide, including improved economic conditions and reduced corruption, rather than the liberal ideals so highly prized in the west (De Waal et al, 2013). A decrease in anti-EU sentiment amongst the Georgian public in 2018 appears to be connected to the visible benefits of signing of the Association Agreement, but also perhaps more saliently the waving of visa requirements for EU travel (Kintsurashvili, 2019:36). This understanding of the EU in terms of what it stands to offer Georgia in more concrete terms, rather than ideological alignment with liberal values, accounts for the popularity in some quarters of APG and GM's Eurosceptic views. 
Michael Cole

University of Tartu

Early Stage Researcher - Fatigue

Thirdly, it is almost impossible to discuss the Georgian far right without assessing the role of Russia, (Stephan, 2018) which has used manipulative strategies (Saari, 2014) to undermine democratisation in countries deemed part of its near abroad (Babayan, 2016), including Georgia. Russia's alleged connections to the two far right populist groups examined in this study, Alliance of Patriots of Georgia (APG) and Georgian March (GM), range from accusations of funding (Transparency International Georgia, 2018), to alignment of ideological and religious values (Stephan, 2018:4). Although APG and GM are keen to distance themselves from 'Pro-Russian' labels (Samkharadze, 2020:7), both are amongst the Georgian far right groups that have, according to Wales (2017), exhibited increasingly noticeable pro-Russian rhetoric in recent years. However, while the precise nature of Russia's influence on APG and GM remains unclear (Stephan, 2018:4), and 'Pro-Russian' labels appear to be overly reductionist (Kincha, 2018), the anti-Western views both groups promote do seem to benefit Russia's interests in Georgia (Stephan, 2018:3).

This seems consistent with the tendency of APG voters tend to hold anti-US and antiWestern views identified by Stephan (2018:4). However, while there may be evidence of correlation, an analysis of the party's official website does not suggest an explicitly anti-US or anti-Western discourse. Instead, it seems more accurate to suggest that the anti-Saakashvili rhetoric, which may find common ground with views emanating from Moscow, potentially facilitates an increased likelihood of APG supporters sympathising with similar narratives Russia promotes, but does not necessarily equate to being pro-Russian. There is a tendency to assume that APG supporters may be inclined to sympathise with Russia due to a shared set of 'traditional' values based on Orthodox Christianity, particularly in relation to illiberal attitudes held towards minorities, including the LGBTQI community, which have contributed significantly to APG's popularity (Wales, 2017). However, it seems that although APG's promotion of these values may indirectly benefit Russia's interests in Georgia, their appeal may be more accurately understood as deriving from their projected image as defenders of Georgian identity from all external influences (Stephan, 2018:3). 
Michael Cole

University of Tartu

Early Stage Researcher - Fatigue

\subsection{Case Studies}

These three features distinguishing Georgian far right populism from other Central and Western European manifestations, partly reflect a tendency in Georgia to define present-day identity through the framework of cultural beliefs and symbols firmly rooted in the past (Batiashvili, 2018:xvii). Thus a deeper knowledge of these factors in the Georgian context, also adds to understandings of the development of far-right populist movements in other countries in the post-Soviet and postcolonial environment undergoing similar processes of national redefinition (Batiashvili, 2018:xvii). To demonstrate how these factors influence the uniquely Georgian 'flavour' of far-right populist approaches to 'doing politics', two high-profile incidents to which GM and APG reacted are discussed. Though a detailed analysis is beyond the scope of the current paper, what follows is a brief overview of each incident followed by a discussion of the Georgian far right's responses.

\subsection{Guram Kashia}

Guram Kashia is a Georgian footballer who currently plays for US club San Jose Earthquakes and the Georgian national team (Almond, 2018). Whilst representing Dutch side Vitesse Arnhem in October 2017, Kashia wore a rainbow-coloured captain's armband in an initiative to promote awareness of the need for equality and diversity in football (Crosby, 2017). Though the decision to wear the armband was made by the Dutch football Union, and not necessarily of Kashia's own volition (Crosby, 2017), the action produced highly polarized reactions amongst Georgians including fierce criticism from the far right (Payne, 2017). Kashia subsequently received the first ever '\#EqualGame Award' for “...championing diversity, inclusion and equality in football" (UEFA, 2018), however, this was not before receiving threats to withdraw from the Georgian national team (UEFA, 2018) and calls for Georgian men to stop attending games in protests against his promotion of 'gay propaganda' (Crosby, 2017). 
Michael Cole

University of Tartu

Early Stage Researcher - Fatigue

\section{Far Right Populist Responses}

Of the two far right populist groups analysed in this study, Georgian March (GM) were the most visible in responding to the Guram Kashia incident. GM demonstrated the confrontational style of politics by organizing street protests, calling for supporters to boycott Georgian national football matches (Baranec, 2018:1) and posting anti-LGBT messages online. GM tried to raise awareness of their campaigns using hashtags on social media including 'Guram We Are Not With You!' (Figure 3), which also demonstrates the dichotomous worldview familiar in populist rhetoric elsewhere. Members of GM, were also central amongst those from the far right, who attended Georgia's international fixture against Latvia, displaying rainbow flags with the initials 'LGBT' crossed out (farenet.com, 2018) and demanding that Kashia apologise publicly for wearing the rainbow armband (Novosti-Gruzia, 2018). Although Alliance of Patriots of Georgia $(A P G)$ made no official statements regarding Guram Kashia, leading member Konstantin Morgoshia stated on national television and online that he would take action to prevent the player representing Georgia against Latvia (Gotsiridze, 2018). Despite the aggressive nature of the statement, when summoned to appear in court, Morgoshia claimed reports he intended to instigate violence against Kashia were false (Gotsiridze, 2018).

The underlying belief of Georgian far right populist actors that Western liberal values are fundamentally incompatible with Georgian national identity (Lebanidze, 2016:2), was also evident, both in the language and symbols used by GM and APG to protests against Kashia. In interviews, GM's leaders made a conscious effort to present Kashia's actions as incompatible with Georgian Orthodox faith, as they 'insult religious sensibilities' (Novosti-Gruzia, 2018).). A closer analysis of the language used in the caption shows GM equating support for LGBT rights with a sinful act, contrary to the strict religious values that they believe are so fundamental to

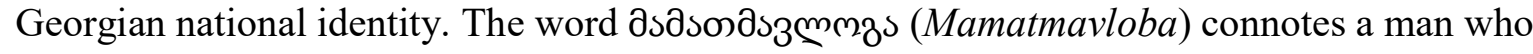
goes to another man for sex, and dsas ( appear in religious contexts, meaning priest. GM's foregrounding of religious values as the primary motive behind their actions facilitates justification of their anti-LGBTQI as it aligns with 
Michael Cole

University of Tartu

Early Stage Researcher - Fatigue

the approach of the Georgian Orthodox Church (GOC). In this sense, GM are reinforcing their projected image as defenders of Georgian values, which are widely agreed upon by the society.

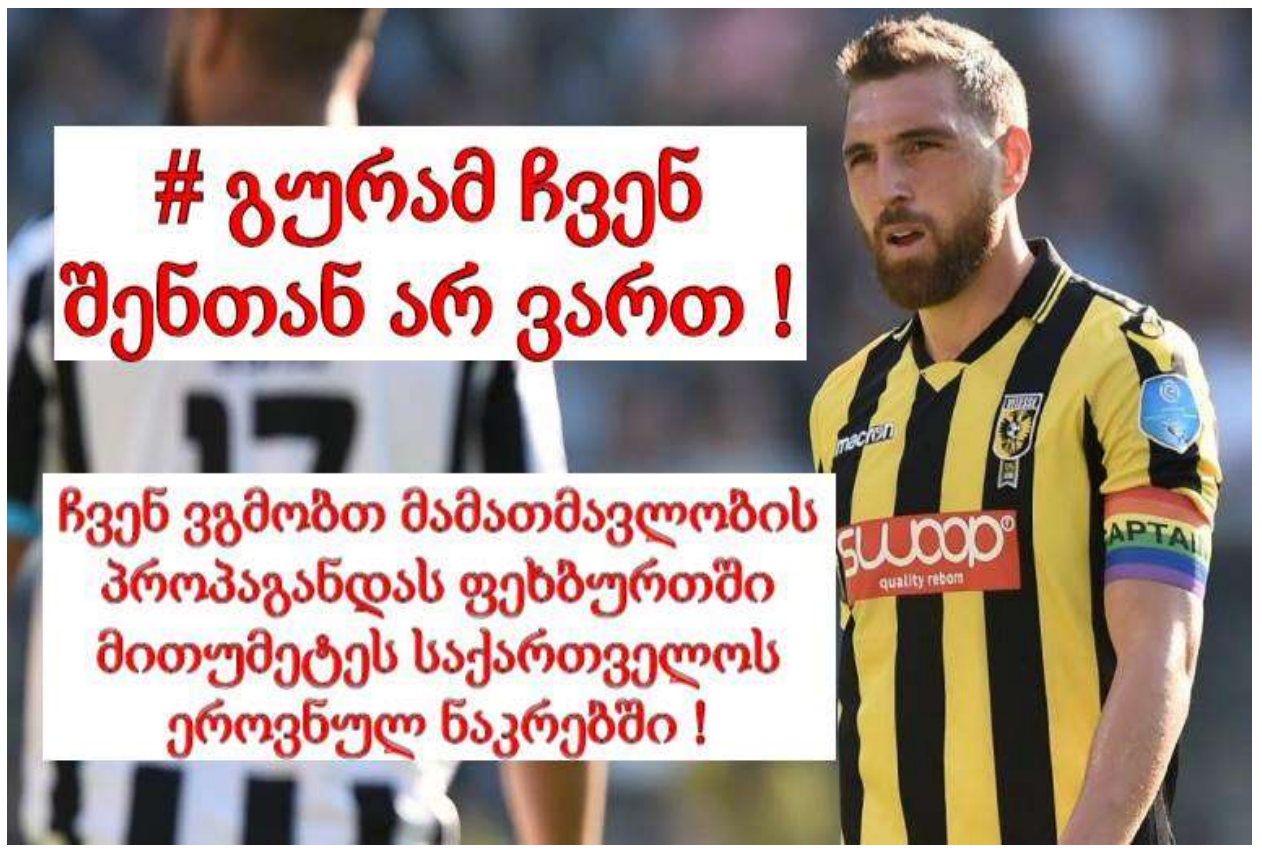

Figure 3: Guram We Are Not With You -

https://www.facebook.com/qartulimarshi/photos/a.184266188783984/338678916676043/?type= 3\&theater

Direct Russian influence on APG and GM's discursive content is challenging to prove conclusively (Stephan, 2018:4). However, the response to Guram Kashia, and LGBTQI issues in general, does suggest certain synergies. Most notably the term 'gay propaganda', which GM often use to describe LGBTQI events including Tbilisi Pride, was also used in response to Kashia (Crosby, 2017). A Facebook post by GM, which has since been removed, contained a picture of Kashia with the caption 'WE CONDEMN HOMOSEXUAL PROPAGANDA IN FOOTBALL - MOST OF ALL IN THE GEORGIAN NATIONAL TEAM!' (Figure 3). The use of the term mirrors language used in Russian laws, which ban 'gay propaganda' (Human Rights 
Michael Cole

University of Tartu

Early Stage Researcher - Fatigue

Watch, 2018) and thus appears indicative of a similar approach to constructing discriminatory narratives which discriminate against the LGBTQI community.

\subsection{And Then We Danced}

And Then We Danced (ATWD) is a film produced by Levin Akin, a Swedish filmmaker with Georgian heritage (Bradshaw, 2020). ATWD's theatrical release in November 2019 provided a further flashpoint between far right and liberal groups in Georgia (Dry, 2019) due to the controversial central love story in the film between two young male dancers in the National Georgian Ensemble (Tartaglione. 2019). Traditional Georgian folk dancing is considered an extremely masculine pursuit (Fisher, 2014:62) and closely associated with Georgian cultural and national identity (Fisher and Shay, 2009:352). Thus, for far right actors including GM and APG, the film represents an insult to notions of Georgian national identity, which according to their conceptualisations of 'the people', exclude members of the LGTQI community. The film has won several awards (Roxborough. 2020), yet it drew an equal amount, if not greater attention from the international press due to the intimidating protests staged by the far right outside Tbilisi cinemas where it was being shown (Dry, 2019).

\section{Far Right Populist Responses}

Georgian March (GM) were also the more vocal of the two far right populist groups studied in this paper, when responding to the release of And Then We Danced (ATWD) in Georgian Cinemas. Through their Facebook page, GM organized further street protests (Figure 6 Below), which on this occasion amounted to barricading Tbilisi's Amirani Cinema to prevent viewers from entering to watch the film, as well as the symbolic burning of rainbow flags, which has become a common feature of GM's protests (Gray, 2019). 
Michael Cole

University of Tartu

Early Stage Researcher - Fatigue

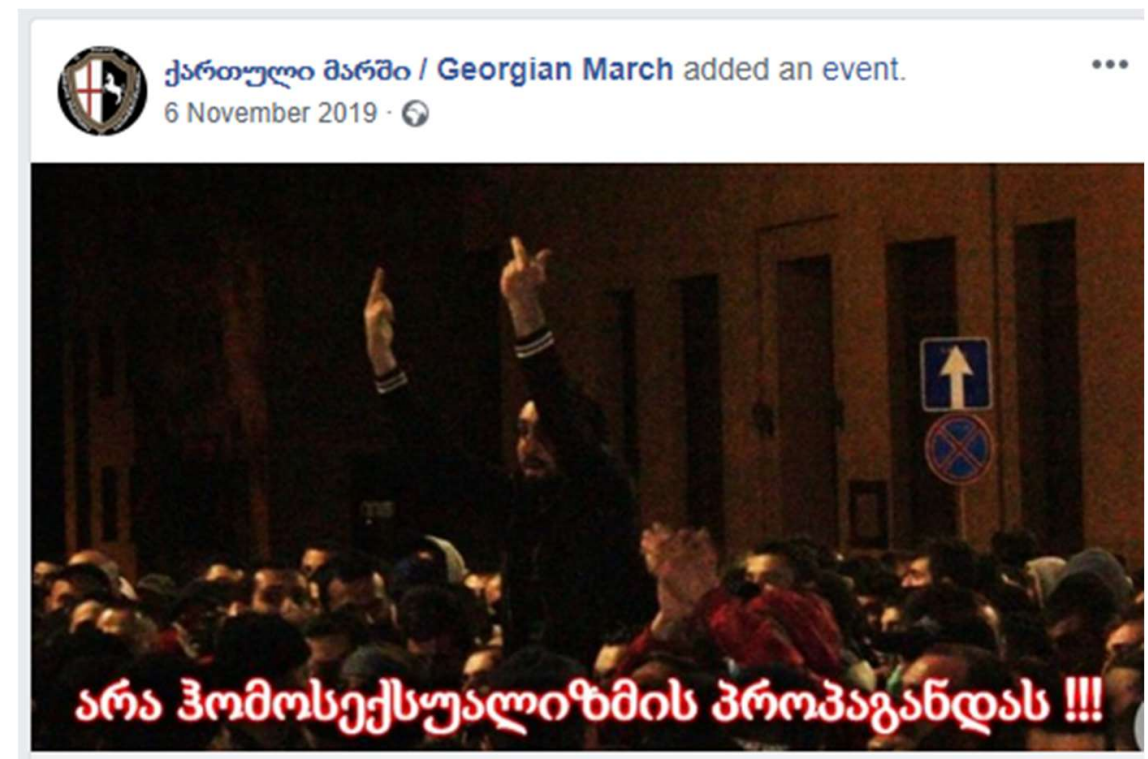

FRI, 8 NOV 2019

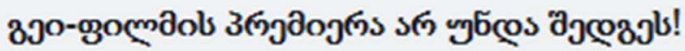

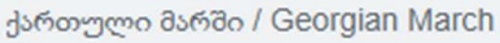

$\star$ Interested

if Home 353 people

Figure 4: Georgian March Event Protest Against 'And Then We Danced' 'No Homosexual Propaganda!' https://www.facebook.com/QartuliMarshiGeorgianMarch/

Alliance of Patriots of Georgia (APG) made no Facebook posts regarding the film, mirrors their official reaction to the Guram Kashia incident. However, APG member Konstantin Morgoshia, who was also involved in protests against Kashia, did play an active role in protests against screenings of ATWD in Tbilisi and Batumi (Dumbadze, 2019). This again seems to demonstrate APG's approach of officially distancing themselves from involvement in acts of aggression, whilst simultaneously allowing party members to participate.

Underscoring this confrontational approach is the prominence of discourses presenting the LGBTQI community as a threat to Georgian identity and Orthodox Christian values. Protestors outside the Amirani Cinema were seen holding religious icons, and members of the church were also active participants (Gray, 2019). In the days immediately prior to, and following the film's screening on November $6^{\text {th }} 2019$, GM also made several Facebook posts featuring an identical caption appears in these posts urging Georgians to protest outside cinemas 
Michael Cole

University of Tartu

Early Stage Researcher - Fatigue

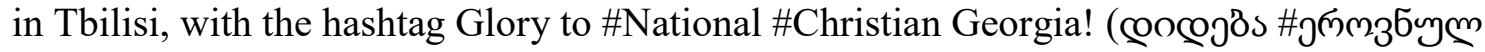

\# „ґо identity with Christianity.

The term 'gay propaganda' was again used widely by Sandro Bregadze to describe the film (Dalton, 2019), and the Facebook posts encouraging GM supporters to protest feature the slogan prominently (Figures 5 and 6 below).

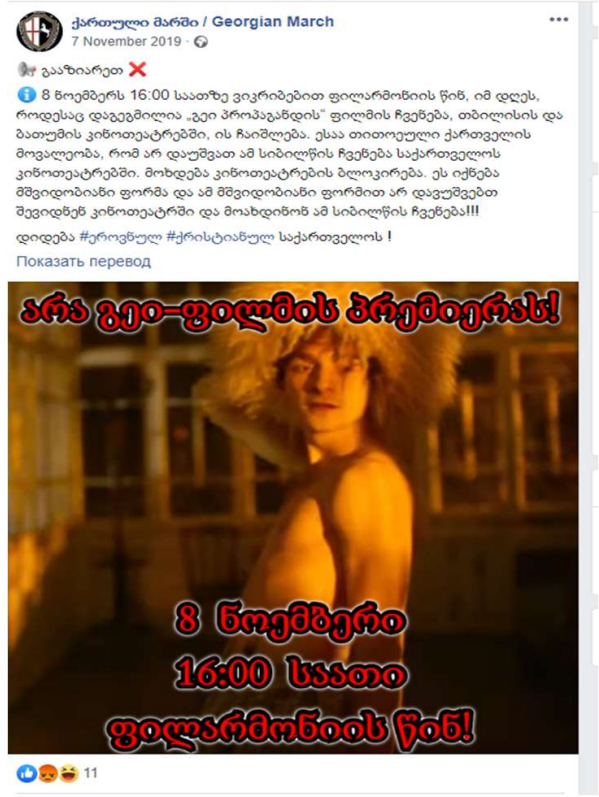

Figure 6: Georgian March Trailer for And Then We Danced https://www.facebook.com/QartuliMarshiGeorgianMarch/

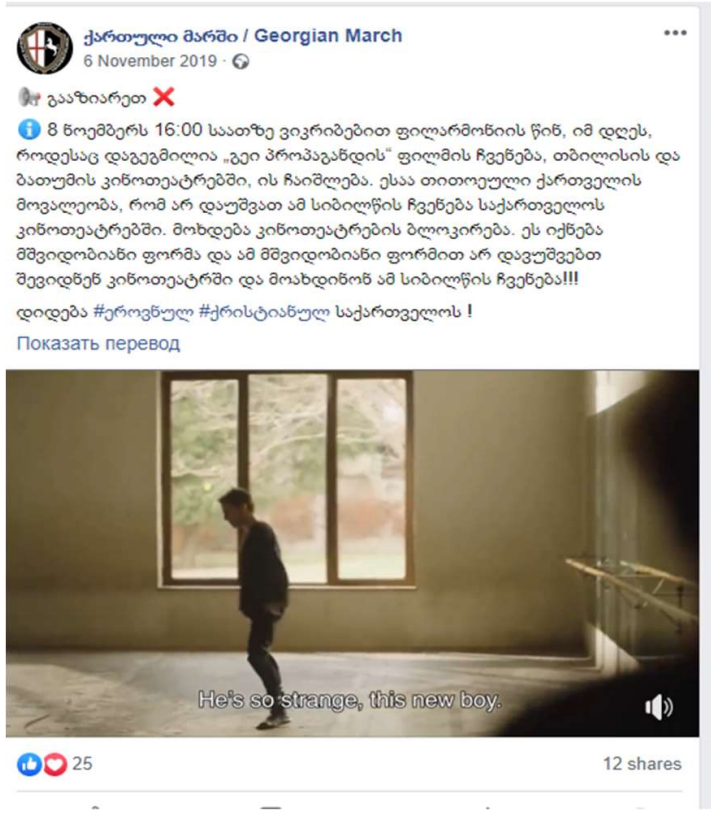

Figure 5: Georgian March Reaction to 'And Then We Danced' https://www.facebook.com/QartuliMarshiGeorgianMarch/

This further resembles the content of Russian anti-LGBTQI discourses targeting the arts, which has led Russian Orthodox Believers to sue Madonna for promoting 'gay propaganda' in Russia for instance (Makarychev and Medvedev, 2015:48). Of further interest perhaps is the relationship between APG's Konstantin Morgoshia and Georgian businessman Levan Vasadze (Lomsadze, 2019), who was also a leading figure in the protests against ATWD. Vasadze was quoted as saying ATWD was "a moral threat to the fabric of our society", (Gray. 2019) thus reinforcing the notion that Georgian national identity is incompatible with LGBTQI rights, and by extension Western liberalism. However, it is Vasadze's alleged connections to controversial 
Michael Cole

University of Tartu

Early Stage Researcher - Fatigue

Russian thinker Alexander Dugin that may suggest a less abstract connection between Russian illiberal discourses and Georgian far right populism (Dumbadze, 2019).

\subsection{Conclusions}

This study first examined the political styles or ways of 'doing politics' of two Georgian far right actors, frequently categorised as populist. The analysis identified that both the Alliance of Patriots of Georgia (APG) and Georgian March (GM) discursively construct homogeneous notions of 'the people', in opposition to the 'elite' or 'enemies'. The application of this dichotomous frame through which events and objects are filtered, is characteristic of the populist political style, and thus supports the view that APG and GM should be considered members of the far right populist 'family'. While not a compulsory feature of populist politics, and acknowledging the relative ambiguity of the concept, both APG and GM are also considered to have charismatic leaders, whose use of the populist discursive frame and style contributes to their appeal in Georgian society.

After locating GM and APG within the wider framework of far right populist actors, the paper then identified three main ways in which Georgian far right populism appears to differ from more frequently studied cases. Firstly, unlike in more frequently examined national contexts, populism has been a common feature of Georgian politics since independence. Secondly, far right Georgian populists hold underlying beliefs that Georgian national identity is fundamentally incompatible with Western democratic ideals. Instead, the synonymity between Georgian identity and Orthodox Christianity, promoted by the Georgian Orthodox Church, creates a rich environment for far right populists to co-opt national and religious symbols to promote extreme views. Thirdly, the influence of Russia as a disruptive influence on Georgian politics cannot be ignored, with far right populists accused of receiving direct support from Moscow.

Having outlined these unique features which constitute the Georgian 'flavour' of far right populist movements in the country, the visibility of these elements was demonstrated through an 
Michael Cole

University of Tartu

Early Stage Researcher - Fatigue

examination of far right populist reactions to two high profile incidents. Both incidents showcased the confrontational and divisive approach typical of the populist political style, but also commonly observed across the Georgian political spectrum. APG and GM responded to the incidents with anti-Western views, which were combined with discursive justifications based on the need to defend the 'traditional' Georgian values promoted by Georgian Orthodox Church (GOC). The discursive alignment with the GOC enables the construction of "chains of equivalence' which significantly contribute to the promotion by APG and GM of more extreme political views. Although further research is required to ascertain the precise nature of APG and GM's relationship with Russia, discursive similarities were evident in the responses to both Guram Kashia and 'And Then We Danced'. 
Michael Cole

University of Tartu

Early Stage Researcher - Fatigue

\section{References}

Abashidze, Z. (2018) 'The Georgian March Against Migrants and NATO' Jam News, $2^{\text {nd }}$ May, 2018. Accessed at: https://jam-news.net/?p=99992

Adam, Z. and Bozoki, A. (2016) 'The God of Hungarians': Religion and Right-Wing Populism in Hungary' Saving the People: How Populists Hijack Religion (2016): 143-144

Agenda.ge (2019) 'Leader of Alliance of Patriots Opposition Breaks into Tbilisi Int'l Conference, Sparks Unrest [VIDEO]' Agenda.ge $10^{\text {th }}$ September 2019. Accessed at: https://agenda.ge/en/news/2019/2411?fbclid=IwAR3TCK8MVrYAVMyieE3t12f851DSlCgRMjs-9rThz038EIxBwtHxBRmRLA

Alliance of Patriots of Georgia (2020) 'Our Party' Official Website Accessed at: http://patriots.ge/about-temp/

Alliance of Patriots of Georgia (2020) 'Our Supporters' Official Website Accessed at: http://patriots.ge/oursupporters

Alliance of Patriots of Georgia (2020) 'Our Vision and Program' Official Website Accessed at: http://patriots.ge/our-vision-program/

Almond, E. (2018) 'How a Rainbow-Colored Armband Led to a Soccer Riot' The Mercury News, August 29th 2018. Accessed at: https://www.mercurynews.com/2018/08/29/how-arainbow-colored-armband-led-to-a-soccer-riot/

Aphrasidze, D. and Siroky, D. (2010) 'Frozen Transitions and Unfrozen Conflicts, Or What Went Wrong in Georgia?' Yale J. Int'l Aff. 5 (2010): 121

Arcimavičienè, L. (2018) 'Self and Other Metaphors as Facilitating Features of Populist Style in Diplomatic Discourse: A Case Study of Obama and Putin's Speeches' in Macaulay, M. (2018) (ed.) Populist Discourse: International Perspectives Toronto: Palgrave MacMillan

Aslanidis, P. (2016a) 'Is Populism an Ideology? A Refutation and a New Perspective' Political Studies 2016, Vol. 64 (IS) 88-104

Aslanidis, P. (2016b) 'Populist Social Movements of the Great Recession' Mobilization: An International Quarterly 21(3):301-321

Babayan, N. (2016) 'The Return of the Empire? Russia's Counteraction to Transatlantic Democracy Promotion in its Near Abroad' in Babayan, N. and Risse, T. (2016) (eds.) Democracy Promotion and the Challenges of Illiberal Regional Powers. Abingdon, New York: Routledge 
Michael Cole

University of Tartu

Early Stage Researcher - Fatigue

Baranec, T. (2018) 'Rise of the Georgian Extreme-Right: Lessons from the EU' STRATPOL Policy Paper: Ministry of Foreign Affairs, Slovakia, 2018

Bar-On, T. (2018) 'The Radical Right and Nationalism’ in Rydgren, J. (2018) (ed.) The Oxford Handbook of the Radical Right: Oxford University Press, pp. 43-74

Batiashvili, N. (2018) The Bivocal Nation: Memory and Identity on the Edge of Empire. Palgrave MacMillan

BBC News Documentary (2018) 'Georgia's Rave Revolution' $30^{\text {th }}$ July 2018 Accessed at: https://www.bbc.com/news/av/world-europe-44999599/georgia-s-rave-revolution

Benford, R. D. and Snow, D. A. (2000) 'Framing Processes and Social Movements: An Overview and Assessment', Annual Review of Sociology, 26, 611-39

Bradshaw, P. (2020) 'And Then We Dance Review - Freewheeling Story of Secret Love' The Guardian 12 ${ }^{\text {th }}$ March 2020. Accessed at: https://www.theguardian.com/film/2020/mar/12/andthen-we-danced-review-levan-akin-georgia

Breeze, R. (2011) 'Critical Discourse Analysis and its Critics' Pragmatics 21:4.493-525

Breeze, R. (2018) 'Representing the People: Claiming the Heartland in Scottish Election Manifestoes' in Macaulay, M. (2018) (ed.) Populist Discourse: International Perspectives Toronto: Palgrave MacMillan

Bregadze, S. (2018) Obieqtivi TV Interview, Ghamis Studia, 22 January Accessed at: http://www.myvideo.ge/v/3504890

Brown, T. (2016) 'Sustainability as Empty Signifier: It's Rise, Fall, and Radical Potential' Antipode Vol. 48 No. 12016 ISSN

Brubaker, R. (2017) 'Why Populism?' Published online in Theory and Society, October 26, 2017 https://doi.org/10.1007/s11186-017-9301-7

Caiani, M., and Della Porta, D. (2011) 'The Elitist Populism of the Extreme Right' Acta Politica, 46, 180-202

Carpentier, N. (2019) 'About Dislocations and Invitations: Deepening the Conceptualization of the Discursive-Material Knot' Discourse, Culture and Organization (pp. 155-178). Palgrave Macmillan, Cham.

Cederström, C. and Spicer, A. (2014) 'Discourse of the Real Kind: A Post-foundational Approach to Organizational Discourse Analysis' Organization, 21(2): 178-205 
Michael Cole

University of Tartu

Early Stage Researcher - Fatigue

Chryssogelos, A. (2018) 'State Transformation and Populism: From the Internationalized to the Neo-sovereign State?’ Politics 1 -16

Civil.ge (2016) 'Six Parliament Vice Speakers Elected' Civil.ge $18^{\text {th }}$ November 2016. Accessed at: https://civil.ge/archives/125939

Civil.ge (2018) 'Alliance of Patriots Holds Anti-UNM Rallies' Civil.ge $26^{\text {th }}$ November 2018. Accessed at: https://civil.ge/archives/267451

Civil.ge (2019) 'Alliance of Patriots Rallies: Land, Faith, Military Non-Alignment and Jobs' Civil.ge 17th June 2019. Accessed at: https://civil.ge/archives/308806

Crosby, A. (2017) 'Top Georgian Footballer Faces Backlash over LGBT Armband' Radio Free Europe, Radio Free Liberty, October $20^{\text {th }} 2017$. Accessed at: https://www.rferl.org/a/georgiafootball-guram-kashia-lgbt-rainbow-homosexuality-discrimination/28806434.html

Dalton, B. (2019) 'And then We Danced' Director Responds to Threat of Protests in Georgia' Screen Daily 8th November 2019. Accessed at: https://www.screendaily.com/news/and-then-wedanced-director-responds-to-threat-of-protests-in-georgia/5144533.article

Dangadze, M. (2019) 'Tarkhan-Mouravi Accuses Turkey of Seizing Georgian Tomatoes and Potatoes' Myth Detector $1^{\text {st }}$ November 2019. Accessed at: https://www.mythdetector.ge/en/myth/tarkhan-mouravi-accuses-turkey-seizing-georgiantomatoes-and-potatoes

DeHanas, D. and Shterin, M. (2018) 'Religion and the Rise of Populism' Religion, State and Society 46:3, 177-185

Democracy and Freedom Watch (2015) 'Opposition Party Calls off Hunger Strike against Election Fraud' Democracy and Freedom Watch November $25^{\text {th }} 2015$ Accessed at: https://dfwatch.net/georgian-opposition-party-calls-off-hunger-strike-39065

Democracy and Freedom Watch (2018) 'Far Right Group has Patrolled Tbilisi Streets for the Last Week' Democracy and Freedom Watch March $6^{\text {th }} 2018$ Accessed at: https://dfwatch.net/far-right-group-patrolled-tbilisi-streets-last-week-50038

De Waal, T., Lipman, M., Gudkov, L. and Bakradze, L. (2013) 'The Stalin Puzzle: Deciphering Post-Soviet Public Opinion' Washington, DC: Carnegie Endowment for International Peace

Dry, J. (2019) 'LGBTQ Film 'And Then We Danced' Stokes Right Wing Protests in Home Country Georgia' IndieWire November $5^{\text {th }} 2019$. Accessed at:

https://www.indiewire.com/2019/11/gay-film-and-then-we-danced-protests-georgia$1202187372 /$ 
Michael Cole

University of Tartu

Early Stage Researcher - Fatigue

EU Neighbours Annual Survey Report (2017) Georgia 2nd Wave (Spring 2017) Open Neighbourhood - Communicating for a Stronger Partnership: Connecting with Citizens across the Eastern Neighbourhood

Eurasia Daily (2018) 'Burn Soros - Save the Country: Another Action of the Georgian March' Eurasia Daily 23 ${ }^{\text {rd }}$ February 2018. Accessed at: https://eadaily.com/en/news/2018/02/23/burnsoros-save-the-country-another-action-of-the-georgian-march

Fairclough, N. (1992) 'Discourse and Social Change' (Vol. 10). Cambridge: Polity press.

Fisher, J. and Shay, A. (2009) When Men Dance: Choreographing Masculinities Across Borders. Oxford University Press

Fisher, J. (2014) 'Why Ballet Men Do Not Stand on their Toes (But Georgian Men Do)' The World of Music, new series, Vol. 3, No. 2, Music, Movement, and Masculinities (2014), pp. 5977

Forchtner, B. (2011) 'Critique, the Discourse-Historical Approach and the Frankfurt School' Critical Discourse Studies, 8:1, 1-14

Freeden, M. (1998) 'Is Nationalism a Distinct Ideology?’ Political Studies (1998), XLVI, 748765

Gamsakhurdia, Z. (1990) 'The Spiritual Mission of Georgia.' Lecture Delivered at the IDRIART Festival in the Tbilisi Philharmonic House, 2 May

Gelashvili, T. (2019) 'Political Opportunities for the Extreme Right in Georgia' Georgian Institute of Politics Policy Brief May 2019, Issue 20

Giesen, B. and Seyfert, R. (2016) 'Collective identities, Empty Signifiers and Solvable Secrets' European Journal of Social Theory 2016, Vol. 19(1) 111-126

Goffman, E. (1974) Frame Analysis: An Essay on the Organization of Experience Boston, MA: Northeastern University Press

Gotsiridze, M. (2018) "We do not want Guram Kashia to play with the shirt of Georgian national team" - one of the leaders of the Patriots Alliance' Rustavi 2 Official Website, 29 ${ }^{\text {th }}$ August 2018: Accessed at: http://web1.rustavi2.ge/en/news/112246

Gray, C. (2019) 'When a Film Shows Gay Romance in Georgia, Going to See it is a Risk The New York Times 6th December 2019. Accessed at:

https://www.nytimes.com/2019/12/06/movies/and-then-we-danced-georgia-protests.html

Hodge, R.I.V. and Kress, G.R. (1988) Social Semiotics. Cornell University Press 
Michael Cole

University of Tartu

Early Stage Researcher - Fatigue

Horvath, R. (2011) 'Putin's 'Preventive Counter-revolution': Post-Soviet Authoritarianism and the Spectre of Velvet Revolution’ Europe-Asia Studies, 63(1), 1-25

Howarth, D. and Stavrakakis, Y. (2000) 'Introducing Discourse Theory and Political Analysis' (2000).

Human Rights Watch (2018) 'No Support: Russia's Gay Propaganda Law Imperils LGBT Youth' Human Rights Watch, December $11^{\text {th }} 2018$. Accessed at:

https://www.hrw.org/report/2018/12/11/no-support/russias-gay-propaganda-law-imperils-lgbtyouth

Humphrey, M. (2013) 'Green Ideology', in Freeden, M., Sargent, L.T, and Stears, M. (eds.) The Oxford Handbook of Political Ideologies Oxford: Oxford University Press, pp. 422-38

Inglehart, R.F. and Norris, P. (2016) 'Trump, Brexit, and the Rise of Populism: Economic Havenots and Cultural Backlash' in Harvard Kennedy School Faculty Research Working Paper Series, RWP16-026, August

Jgharkava, I. (2017) 'Anti-migrant Rhetoric in Georgia: Do Far-right Groups Threaten Georgia's Pro-European Discourse?' Georgian Institute of Politics Issue\#16 August 2017

Jones, S. (2015) Georgia: A Political History Since Independence. IB Tauris

Kallis, A. (2018) 'The Radical Right and Islamophobia' in Rydgren, J. (2018) (ed.) The Oxford Handbook of the Radical Right: Oxford University Press, pp 76-101

Karatnycky, A. (2018) 'The Rise and Fall of Mikheil Saakashvili' Politico $2^{\text {nd }}$ February 2018. Accessed at: https://www.politico.eu/article/the-rise-and-fall-of-mikheil-saakashvili/

Kekelia, T. (2014) 'Building Georgian National Identity: A Comparison of Two Turning Points in History' in Agadjanian, A., Jödicke, A, and Van der Zweerde, E. (2014) (Eds.) Religion, Nation and Democracy in the South Caucasus Routledge

Kincha, S. (2018) 'Labelling Georgia's Far-Right 'Pro-Russian' is Reductionist and Counterproductive' OC Media $13^{\text {th }}$ August 2018. Accessed at:

https://oc-media.org/opinion-labelling-georgias-far-right-pro-russian-is-reductionist-andcounterproductive/

Kintsurashvili, T. (2019) 'Anti-Western Propaganda Media Monitoring Report 2018' Media Development Foundation, 2019.

Kucera, J. (2016) 'Georgia: Disillusion With Establishment Fuels Rise of Populism' Eurasianet $24^{\text {th }}$ October 2016. Accessed at: https://eurasianet.org/georgia-disillusion-establishment-fuelsrise-populism 
Michael Cole

University of Tartu

Early Stage Researcher - Fatigue

Kvakhadze, A. (2018) 'Security Review: Far-Right Groups in Georgia' Georgian Foundation for Strategic and International Studies Accessed at: https://www.gfsis.org/publications/view/2666

Laclau, E. (1988) 'Metaphor and Social Antagonisms' In Nelson, C. and Grossberg, L. (Eds.), Marxism and the Interpretation of Culture (pp. 249-257). Urbana: University of Illinois

Laclau, E. (1996) ‘Why do Empty Signifiers Matter to Politics?’ Emancipation(s), 36, 46

Laclau, E. (2005) On Populist Reason Verso: London, New York

Laclau, E. and Mouffe, C. (2001) Hegemony and Socialist Strategy: Towards a Radical

Democratic Politics, Second Edition London, New York: Verso

Lebanidze, B. (2016) 'Democracy Under Stress: Western Fatigue, Russian Resurgence, and their Implications for Democratic Processes in Georgia' Georgian Institute of Politics, Policy Paper, February 2016

Locke, T. (2004) Critical Discourse Analysis London, New York: Continuum

Lomsadze, G. (2018) 'Can a Reclining Georgian Nationalist Fake His Way to the Top?'

Eurasianet $23^{\text {rd }}$ April, 2018. Accessed at: https://eurasianet.org/can-a-reclining-georgiannationalist-fake-his-way-to-the-top

Makarychev, A. and Medvedev, S. (2015) Biopolitics and Power in Putin's Russia, Problems of Post-Communism, 62:1, 45-54

Makarychev, A. and Sazonov, V. (2019) 'Populisms, Popular Geopolitics and the Politics of Belonging in Estonia' European Politics and Society, 1-20

Mchedlishvili, E. (2018) 'В Грузии напали на журналистов за "оскорбление Христа"” Настоящее Время 21 ${ }^{\text {st }}$ March 2018. Accessed at: https://www.currenttime.tv/a/29111760.html

Mestvirishvili, M., Zurabishvili, T., Tamar Iakobidze, T., and Mestvirishvili, N. (2017)

'Exploring Homophobia in Tbilisi, Georgia' Journal of Homosexuality, 64:9

Minesashvili, S. (2017) 'The Orthodox Church in the Democratisation Process in Georgia:

Hindrance or Support?’ Caucasus Analytical Digest 2017 6-9

Moffitt, B. and Tormey, S. (2014) 'Rethinking Populism: Politics, Mediatisation and Political Style’ Political Studies: 2014, Vol. 62 381-397

Moffitt, B. (2016) The Global Rise of Populism: Performance, Political Style, and Representation. Stanford, California: Stanford University Press 
Michael Cole

University of Tartu

Early Stage Researcher - Fatigue

Morrison, T. (2018a) 'Georgian Church Launches Annual March on Family Purity Day' Georgia Today, 17 $7^{\text {th }}$ May 2018. Accessed at: http://georgiatoday.ge/news/10313/Georgian-ChurchLaunches-Annual-March-on-Family-Purity-Day

Morrison, T. (2018b) 'Alliance of Patriots Holds Protest Rally against UNM' Georgia Today 26th November 2018. Accessed at: http://georgiatoday.ge/news/13361/Alliance-of-PatriotsHolds-Protest-Rally-against-UNM

Morrison, T. (2018c) 'Ultranationalist Georgian March Holds Anti-Soros Protest Rally' Georgia Today 23rd February 2018. Accessed at: http://georgiatoday.ge/news/9232/UltranationalistGeorgian-March-Holds-Anti-Soros-Protest-Rally

Mudde, C. (2004) 'The Populist Zeitgeist' Government and Opposition 39(4), 541-563

Mudde, C. (2014) 'The Far Right and the European Elections' Current History, 113(761), 98103.

Mudde, C. and Kaltwasser, C.R. (2017) Populism: A Very Short Introduction. New York: Oxford University Press

Müller, M. (2008) 'Reconsidering the Concept of Discourse for the Field of Critical Geopolitics: Towards Discourse as Language and Practice’ Political Geography 27 (2008) 322-338

Odmalm, P. and Hepburn, E. (2018) 'Mainstream Parties, the Populist Radical Right and the (alleged) Lack of Restrictive and Assimilationist Alternative' in Odmalm, P., and Hepburn, E. (2018) (eds.) The European Mainstream and the Populist Radical Right, Taylor and Francis 2017

Pappas, T.S. (2016) 'Are Populist Leaders "Charismatic”? The Evidence from Europe Constellations, 23(3), 378-390

Payne, M. (2017) 'Georgian Soccer Star Called on to Resign from National Team for Wearing Rainbow Captain's Armband' Washington Post, October $21^{\text {st }} 2017$. Accessed at: https://www.washingtonpost.com/news/early-lead/wp/2017/10/21/georgian-soccer-star-calledon-to-resign-from-national-team-for-wearing-rainbow-captains-band/?utm term=.642b15ed9e 71

Pertaia, L. (2017) 'Who Was in and Who Was Out in Tbilisi's Far-Right March of Georgians [Analysis] ' OC Media July 17 $7^{\text {th }}$ 2017: Accessed at: https://oc-media.org/who-was-in-and-whowas-out-in-tbilisis-far-right-march-of-georgians-analysis/

Roxborough, S. (2020) 'And Then We Danced' Wins Best Picture at Swedish Film Awards' The Hollywood Reporter $21^{\text {st }}$ January 2020, Accessed at:

https://www.hollywoodreporter.com/news/we-danced-wins-best-picture-at-swedish-film-awards1271611 
Michael Cole

University of Tartu

Early Stage Researcher - Fatigue

Saari, S. (2014) 'Russia's Post-Orange Revolution Strategies to Increase

its Influence in Former Soviet Republics: Public Diplomacy po russkii’, Europe-Asia Studies, 66:1,50-66

Samkharadze, N. (2020) 'Deconstructing Modern Georgian Populism: Narratives From Political Parties to Social Movements' Georgian Institute of Politics Policy Memo February 2020, Issue 33

Sawyer, R.K. (2002) 'A Discourse on Discourse: An Archeological History of an Intellectual Concept' Cultural Studies, 16:3, 433-456

Sikharulidze, A. (2019) 'The Elite Supper' Georgia Today $17^{\text {th }}$ October 2019. Accessed at: http://georgiatoday.ge/news/17775/The-Elite-Supper

Silagadze, G. (2020) "Who is (Not) Populist in Georgia? Making Sense of the Buzzword" Georgian Institute of Politics Policy Memo February 2020, Issue 34

Stanley, B. (2008) ‘The Thin Ideology of Populism’ Journal of Political Ideologies, 13(1), pp $95-110$

Stephan, A. (2018) 'Defining the Far-Right in Georgia: From Neo-Fascists to Populist Parties' Georgian Institute of Politics Policy Paper No. 5 Tbilisi, October 2018

Tartaglione, N. (2019) 'And Then We Danced's Levan Akin Talks Swedish Oscar Entry and Georgian Controversy’ Deadline Accessed at: https://deadline.com/2019/11/levan-akininterview-and-then-we-danced-protests-international-feature-film-oscar-1202785785/

Transparency International Georgia (2018) ‘Anatomy of Georgian Neo-Nazism’ May 18, 2018 Accessed at: https://www.transparency.ge/en/blog/anatomy-georgian-neo-nazism

UEFA (2018) 'Kashia proud of UEFA \#EqualGame Award' 30 ${ }^{\text {th }}$ August 2018, Accessed at: https://www.uefa.com/insideuefa/social-responsibility/news/newsid=2568477.html

Unknown Author (2013) BBC 'Thousands Protest in Georgia Over Gay Rights Rally' $17^{\text {th }}$ May 2013, Accessed at https://www.bbc.com/news/world-europe-22571216

Unknown Author (2018) 'Georgian Footballer Guram Kashia Given UEFA \#EqualGame Award for LGBT Support' Farenet.com, $31^{\text {st }}$ August 2018. Accessed at: https://farenet.org/lgbt-termslug/georgian-footballer-guram-kashia-given-uefa-equalgame-award-for-lgbt-support/

Unknown Author (2018) 'Грузинский марш» требует от Кашия извинений за оскорбление «религиозных чувств’ Novosti-Gruzia, $9^{\text {th }}$ September 2018. Accessed at: https://www.newsgeorgia.ge/gruzinskij-marsh-trebuet-ot-kashiya-izvinenij-za-oskorblenie$\underline{\text { religioznyh-chuvstv/ }}$ 
Michael Cole

University of Tartu

Early Stage Researcher - Fatigue

Wales, O. (2017) 'Georgian Far-Right Nationalism and the Russian Factor' Accessed at: http://regional-dialogue.com/en/georgian-far-right-nationalism-and-the-russian-factor/

Weiss, G., and R. Wodak (2002) 'Introduction: Theory, Interdisciplinarity and Critical Discourse Analysis' in Weiss, G. and Wodak, R. (eds.), Critical Discourse Analysis: Theory and Interdisciplinarity. London: Palgrave Macmillan, pp. 1-32.

Williams, M.H. (2018) 'The Political Impact of the Radical Right' in Rydgren, J. (2018) (ed.) The Oxford Handbook of the Radical Right Oxford University Press, pp 440-467

Wodak, R., and Fairclough, N. (1997) 'Discourse as Social Interaction' Discourse Studies. A Multidisciplinary Introduction II.

Zedania, G. (2011) 'The Rise of Religious Nationalism in Georgia' Identity Studies in the Caucasus and the Black Sea Region, 3. 